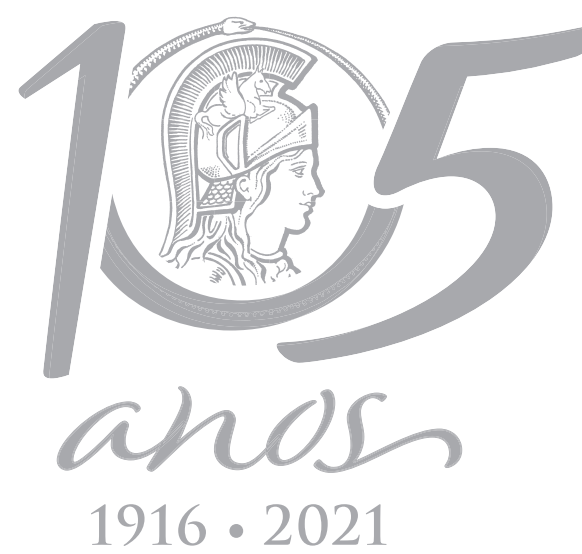

\title{
Evaluation of Antitermite Properties of Wood Extracts from Pongamia pinnata (L.) Pierre (Leguminosae) against Subterranean Termites
}

\author{
SOHAIL AHMED, MUZAMMAL H. TABASSUM \& BABAR HASSAN
}

\begin{abstract}
Termiticide, repellent and antifeedant activities of extracts from Pongamia pinnata wood were evaluated against Coptotermes heimi (Wasmann) at three different concentrations preceded by a preliminary choice and no-choice tests for natural resistance of tested wood. Termites' mortality was determined in each case of extract

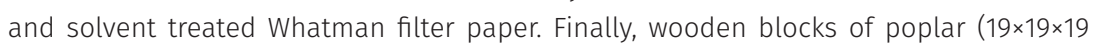
$\mathrm{mm}$ ) were treated with extracts and respective solvents and exposed to termites in the field for 28 days. Minimum mean weight loss was observed in dried P. pinnata (6.38\%), followed by fresh $P$. pinnata in choice tests. In no-choice tests, dried P. pinnata was comparatively resistant with a weight loss of $12.37 \%$, followed by fresh $P$. pinnata and P. deltoides. In toxicity bioassay, ethyl acetate-based wood extracts caused the highest mortality (41.66\%), followed by petroleum ether, hexane, and water extracts at $10 \mathrm{mg} /$ $\mathrm{ml}$ concentration. Similarly, ethyl acetate-based extracts showed maximum repellency (100\%) followed by petroleum ether extracts at $10 \mathrm{mg} / \mathrm{ml}$ and ethyl acetate at $5 \mathrm{mg} /$ $\mathrm{ml}$ after $60 \mathrm{~min}$ of termite exposure. Minimum wood losses were observed in woods treated with ethyl acetate extracts compared to control and other treatments in field experiments.
\end{abstract}

Key words: choice test, extracts, no-choice test, repellency, termites, toxicity.

\section{INTRODUCTION}

Naturally durable wood species possess material characteristics that can often delay biodeterioration by fungi and insects (Kadir et al. 2014). Heartwood extractive content has been shown to be an important contributor to the inherent durability of these wood species (Kirker et al. 2013). Previous studies showed that removal of extracts from durable woods make them susceptible to termites' attack and other wood deteriorating agents and suggested that the extracts have a vital impact on wood durability (Kirker et al. 2013, Hassan et al. 2016, 2018a, b, 2019a, b).
On the other hand, susceptible wood species can be made durable by the application of certain synthetic preservatives. Synthetic wood preservatives, despite their advantages, pose environmental concerns because of their toxicity and persistence (Ahmed et al. 2014, 2016, 2017, Fatima et al. 2015). There is a need for wood preservation strategies with lower environmental impacts and reduced effects on non-target species. Under this supposition, extracting toxic fractions from naturally durable wood species and using them as wood preservatives for susceptible wood is one strategy to reduce environmental and health hazards (GonzálezLaredo et al. 2015). Chemically, these extracts include flavonoids, alcohols, terpenes, 
alkaloids, glycosides, esters, stilbenes, phenols, polyphenols, and water-soluble compounds having insecticidal, antifungal and antimicrobial activities (Kaur et al. 2016, Hassan at al. 2017).

Pongamia pinnata (L.) is an evergreen medium-sized leguminous tree bearing seeds having $30-40 \%$ oil in them. Nineteen biologically active constituents have been isolated and identified from this tree being used in pharmaceutics(Kumar\&Singh2002). Leafextracts of $P$. pinnata possessed excellent antimicrobial activity against Micrococcus sp. (Chopade et al. 2008). Ethanolic and methanolic leaf extracts of $P$. pinnata possessed anti-inflammatory, antidiarrhoeal and anti-ulcer activities (Sagwan et al. 2012). Petroleum ether leaf extracts of P. pinnata exhibited ovicidal and anti-lice activity by delaying the emergence of nymphs (Samuel et al. 2009). In combination with Kigelia africana (Lam), Benth, bark, and leaf extracts of $P$. pinnata has a synergistic effect in causing mortality of Aedes aegypti (Linnaeus) (Al-Solami et al. 2014). Methanol seed extracts of $P$. pinnata deterred gravid females of Helicoverpa armigera (Hübner) from egg-laying and larvae feeding on the substrate. The adults feeding on the treated subject showed a conspicuous reduction in egg-laying capacity, and lower hatchability (Reena et al. 2012). Methanol seed extracts of $P$. pinnata possessed excellent insecticidal activity against Nilaparvata lugens (Stål) (Hiremath et al. 1997). Seed extracts of P. pinnata also contain certain active compounds effective against subterranean termite, Odontotermes obesus (Rambur) (Verma et al. 2011). However, extracts from the wood of $P$. pinnata have not been tested as wood preservatives against subterranean termites. This tree is locally known as Sukhehein or Sukh-Chain in Urdu, Karanja or Karanj in Hindi, and Indian beech in English (Sangwan et al. 2010). In the present study, the toxicity of $P$. pinnata heartwood extracts was tested against a subterranean termite, Coptotermes heimi (Wasmann), via exposing termites to heartwood compounds extracts on the filter paper. Extracts were removed from wood through cold extraction using four solvents, and their toxicities were tested and then were used to preserve non-durable wood against subterranean termite species

\section{MATERIALS AND METHODS}

\section{Selection of woods and sample preparation}

A small log of $P$. pinnata wood was obtained from Patron Potato Processing Factory, Depalpur, Pakistan, that was cut from its main log. The size of this small log was $55 \times 200 \mathrm{~cm}$ having more than $70 \%$ of heartwood. Populus deltoides (30 $\times$ $100 \mathrm{~cm}$ ) was purchased from the Timber Market of Hujra Shah Muqeem, Okara, Pakistan. For choice and no-choice tests, wooden stakes of $10 \mathrm{~cm}(\mathrm{t}) \times 5 \mathrm{~cm}(\mathrm{r}) \times 2 \mathrm{~cm}(\mathrm{l})$ size from $P$. pinnata and $P$. deltoides (fresh) were prepared by using an electric saw from freshly cut air-dried logs. All the stakes were free of knots and showed no infection by molds, stains, or wood-destroying fungi and insects. To prepare extracts, a small part of $P$. pinnata heartwood was converted into shavings using a fine electric planer.

\section{Preparation of extracts}

Wood shavings were air-dried under shade in Termite Research Laboratory before extraction. Four solvents (water, ethyl acetate, hexane and petroleum ether) were used to extract wood shavings. We followed a method adopted by Ahmed et al. (2018) to prepare extracts. A total of $115 \mathrm{~g}$ of air-dried wood shavings were added in a reagent bottle containing 2.5 liters of each solvent separately. The bottles were shaken at regular intervals for 20 days. The obtained extract-solvent mixture was then filtered using a muslin cloth, and the filtrate of each solvent was 
evaporated through a rotary evaporator. After evaporation, stock solutions were made (10 mg/ $\mathrm{ml})$ to prepare different concentrations $(2.5 \mathrm{mg} /$ $\mathrm{ml}, 5 \mathrm{mg} / \mathrm{ml}$ and $10 \mathrm{mg} / \mathrm{ml}$ ) in their respective solvents to test the termiticidal activities in different experiments.

\section{Collection of termites}

Termite workers were collected from the wood buried in the ground and corrugated cardboard in PVC monitors installed at the PARS, Jhang Road, University of Agriculture, Faisalabad, and from Botanical Garden, Forman Christian College, Lahore (Ahmed et al. 2014). Termites collected from different places were brought to the laboratory and identified using available key (Ahmad 1955, Akhtar 1975). Termite was identified as Coptotermes heimi (Wasmann) and was kept in Petri plates $(90 \mathrm{~mm} \times 15 \mathrm{~mm})$ containing moist filter papers in the laboratory at $26 \pm 2^{\circ} \mathrm{C}$, and $80 \%$ R.H.

\section{Natural resistance of $P$. pinnata wood in choice and no-choice field tests}

Stakes of $P$. pinnata heartwood $(10 \mathrm{~cm} \times 5 \mathrm{~cm} \times$ $2 \mathrm{~cm}$ ) were installed in the field to determine its natural resistance against subterranean termites along with $P$. deltoides stakes $(10 \mathrm{~cm}$ $\times 5 \mathrm{~cm} \times 2 \mathrm{~cm}$ ) as a positive control (Ahmed et al. 2014). In the choice test, each of $P$. pinnata sun-dried, P. pinnata fresh, and P. deltoides (fresh) stakes were tied together with the help of copper wire in different combinations ( $P$. deltoides + fresh P. pinnata $+P$. deltoides, $P$. deltoides + dried $P$. pinnata + P. deltoides, fresh $P$. pinnata + P. deltoides + fresh P. pinnata, dried $P$. pinnata $+P$. deltoides + dried $P$. pinnata, and fresh $P$. pinnata $+P$. deltoides + dried P. pinnata). These tied wooden stakes were offered to preinvited termites by burying them underground in the field for 28 days to examine the weight losses in termites' highly infested site at PARS,
Jhang Road, University of Agriculture, Faisalabad. In the no- choice test, wooden stakes from sundried P. pinnata, fresh P. pinnata, and P. deltoides (fresh) were buried underground separately for 28 days to examine the weight losses. There were three replicates for each treatment in each test, and the experiment was laid out in Randomized Complete Block Design.

\section{Mortality bioassay on treated filter paper}

We followed the method described by Hassan et al. (2017) with some modifications for filter paper toxicity bioassay. Briefly, the experiment was conducted in small plastic trays with Whatman filter paper No. 42 of $9 \mathrm{~cm}$ diameter. Filter papers were treated with extracts at three different concentrations $(2.5 \mathrm{mg} / \mathrm{ml}, 5 \mathrm{mg} / \mathrm{ml}$, and $10 \mathrm{mg} / \mathrm{ml}$ ) along with control treatments (with respective solvents and water). After drying of filter papers in the fume hood, 50 termite workers were released in the plastic tray. There were three replications for each treatment. The mortality was recorded every 3 hours up to 24 hours by counting the live number of termites in all treatments. Mortality and weight loss of filter paper were calculated at the end of the experiment.

\section{Repellent and Antifeedancy Tests}

Whatman filter papers (9 $\mathrm{cm}$ diameter) were sliced into two halves; one-half of filter paper was treated with $1 \mathrm{ml}$ of each concentration of extracts, and the other half was treated with the respective solvent only. One-half was treated either water or solvent for water and solvent control while the second half was left untreated. After drying the filter paper under the fume hood, both halves (extracts treated and only respective solvent/water treated control) were rejoined by placing the adhesive tape underside of the filter paper halves. These rejoined filter papers were then placed in Petri dishes (diameter; 9.1 $\mathrm{cm}$ ), and 50 active termites were released in the 
center of the rejoined filter paper. The number of termites on treated and untreated halves were recorded after 60 minutes. To calculate percent repellency following formula was used (Kadir et al. 2014).

$$
\text { Repellent \% }=(N c-N t) /(N c+N t) \times 100
$$

Where Nc is the total number of termites in the control halve while $\mathrm{Nt}$ is the total number of termites on the treated filter paper halve. Antifeedancy indices (Absolute coefficient of antifeedancy A) were determined on the basis of weight loss of filter paper during filter paper bioassay using the following formula (Hassan et al. 2018a).

$$
A \%=[(K K-E E) /(K K+E E)] \times 100
$$

Where $\mathrm{KK}=$ Weight loss of filter paper in control treatment, $\mathrm{EE}=$ Weight loss of treated filter paper.

\section{Efficacy of wood extracts of $P$. pinnata against subterranean termites on $P$. deltoides wood in field tests}

Weighed and conditioned $\left(33^{\circ} \mathrm{C}\right.$ and $62 \pm 3 \%$ R.H.) blocks of $P$. deltoides $(45 \mathrm{~mm} \times 19 \mathrm{~mm} \times 19 \mathrm{~mm})$ were treated by dipping in extracts, and vacuum pressure treatment at different concentrations $(2.5,5$ and $10 \mathrm{mg} / \mathrm{ml})$ of $P$. pinnata heartwood extracts separately. For control treatments, blocks were treated with respective solvents only. P. pinnata blocks were dipped in a 500$\mathrm{ml}$ beaker with each extract concentration for 72 hours for dipping treatment. While for vacuum pressure treatment, three blocks for each treatment were placed in a beaker with the respective concentration of extracts. The beaker containing blocks was held under vacuum for 60 min, and then the pressure was applied at 40 psi for $60 \mathrm{~min}$. Then blocks were blotted, dried using paper towels, weighed, and re-conditioned at $33^{\circ} \mathrm{C}$, and $62 \pm 3 \%$ R.H. Treated blocks were then offered to pre-invited termites by burying them underground at the site mentioned above. All treatments were replicated three times. Data on weight loss were taken after 28 days, and mass losses of the wooden blocks was determined by using the following formula (Ahmed et al. 2014).

$$
\text { Weight loss }=\frac{W_{1}-W_{2}}{W_{1}} \times 100
$$

Where $W_{1}=$ Initial weight of the block, $W_{2}=$ Final weight of the block.

\section{Statistical analysis}

Mortality, repellency, antifeedancy, and weight loss data were analyzed using a factorial design. Data obtained were analyzed by using Minitab16 and Statistix statistical software.

\section{RESULTS}

\section{Natural resistance of $P$. pinnata wood against subterranean termites in choice and no-choice field tests}

Weight loss of P. pinnata wood offered to termites in choice, and no-choice test is shown in Table I. Overall, P. pinnata wood was resistant to termites when compared with $P$. deltoides wood (positive control). Weight loss was significantly higher $(21.79 \%)$ in the case of $P$. deltoides even with sun-dried P. pinnata combination and fresh P. pinnata. Whereas the lowest weight loss (6.38\%) was recorded in sundried $P$. pinnata in the choice test. In a no-choice test, dried $P$. pinnata was moderately resistant against termites, and significantly lower weight loss (12.37\%) was recorded.

\section{Filter paper toxicity test}

Mortality of termites after 24 hours of exposure to different extracts at three concentrations is shown in Fig. 1. Mortality was significantly higher (41.66\%) in termites fed on filter paper treated with ethyl acetate extract at $10 \mathrm{mg} / \mathrm{ml}$ concentration. However, at lower concentrations of ethyl acetate extracts, mortality differed 
Table I. Comparison of mean weight losses of fresh P. pinnata, sun-dried P. pinnata, and P. deltoides after 28 days exposure to subterranean termites in choice and no-choice field tests.

\begin{tabular}{|c|c|c|c|c|c|c|}
\hline \multirow{2}{*}{ Wood types } & \multicolumn{5}{|c|}{ Weight loss (\%) } & No-choice test \\
\cline { 2 - 7 } & \multicolumn{5}{|c|}{ Choice test } \\
\cline { 2 - 7 } & P+F+P & P+D+P & F+P+F & D+P+D & P+D+F & \\
\hline Fresh P. pinnata & $10.73 \pm 1.55^{\mathrm{b}}$ & - & $8.57 \pm 2.17^{\mathrm{b}}$ & - & $7.66 \pm 2.17^{\mathrm{b}}$ & $16.05 \pm 2.97^{\mathrm{B}}$ \\
\hline Dried P. pinnata & - & $6.38 \pm 1.51^{\mathrm{C}}$ & - & $8.46 \pm 1.54^{\mathrm{c}}$ & $8.88 \pm 1.39^{\mathrm{C}}$ & $12.37 \pm 1.75^{\mathrm{C}}$ \\
\hline Fresh P. deltoides & $20.84 \pm 1.15^{\mathrm{a}}$ & $20.56 \pm 0.38^{\mathrm{a}}$ & $20.10 \pm 0.15^{\mathrm{a}}$ & $21.79 \pm 0.92^{\mathrm{a}}$ & $20.82 \pm 0.30^{\mathrm{a}}$ & $35.61 \pm 7.56^{\mathrm{A}}$ \\
\hline
\end{tabular}

Means sharing different letters are significantly different from one another $F=13.76,9.42, p<0.05 . P=P$. deltoides, $F=f r e s h$. pinnata, $\mathrm{D}=$ dried $P$. pinnata.

non-significantly with other extracts except water extract, the latter recorded the lowest mortality. After feeding on filter paper, the mortality of termites treated with water extract was statistically similar with hexane and petroleum ether extract at $10 \mathrm{mg} / \mathrm{ml}$. Minimum mortality $(<12 \%)$ was observed in termites fed on filter paper treated with only solvents or water (control treatment).

\section{Repellency test}

Termites were significantly very repellent towards ethyl acetate extract of $P$. pinnata wood at the highest concentration $(10 \mathrm{mg} / \mathrm{ml})$ compared to its solvent control that differed significantly from petroleum ether (96\%) and $\mathrm{n}$-hexane (86.67\%) extracts. At $2.5 \mathrm{mg} / \mathrm{ml}$ concentration, ethyl acetate extracts' repellency was similar to $n$-hexane and water extracts. The lowest repellency was seen in water extract at all concentrations where an almost equal number of termites were present on extract and water treated halves of filter paper. Repellency in water extract had a significant difference with petroleum ether and hexane extracts in addition to ethyl acetate extracts (Fig. 2).

\section{Anti-feedant test}

Antifeedant activities of different concentrations of $P$. pinnata $n$-Hexane, petroleum ether, ethyl acetate and water extracts are shown in Fig. 3. Results of this test were not very much different from the repellency test at the highest concentration, whereas behavior was not evident at lower concentrations. Extracts at low concentrations showed non-significant antifeedant values with water extracts which was not the case in the repellency test (Fig. 3).

\section{Field trials}

Maximum weight loss (51\%) was observed in the control treatment, while minimum percent weight loss (14\%) was observed in wooden stakes treated with ethyl acetate extracts $(10 \mathrm{mg} / \mathrm{ml})$. Controls in each extract case had significantly high weight loss when compared with the corresponding solvent under the dipping experiment (Fig. 4). Weight loss in wooden stakes treated with extracts under vacuum pressure application presented the similarity with dipping experiment (Fig. 5); however, numerically, weight loss was less than that of dipping experiment. Overall, ethyl acetate extracts showed more protection of $P$. deltoides, followed by petroleum ether, hexane, and water extracts. 


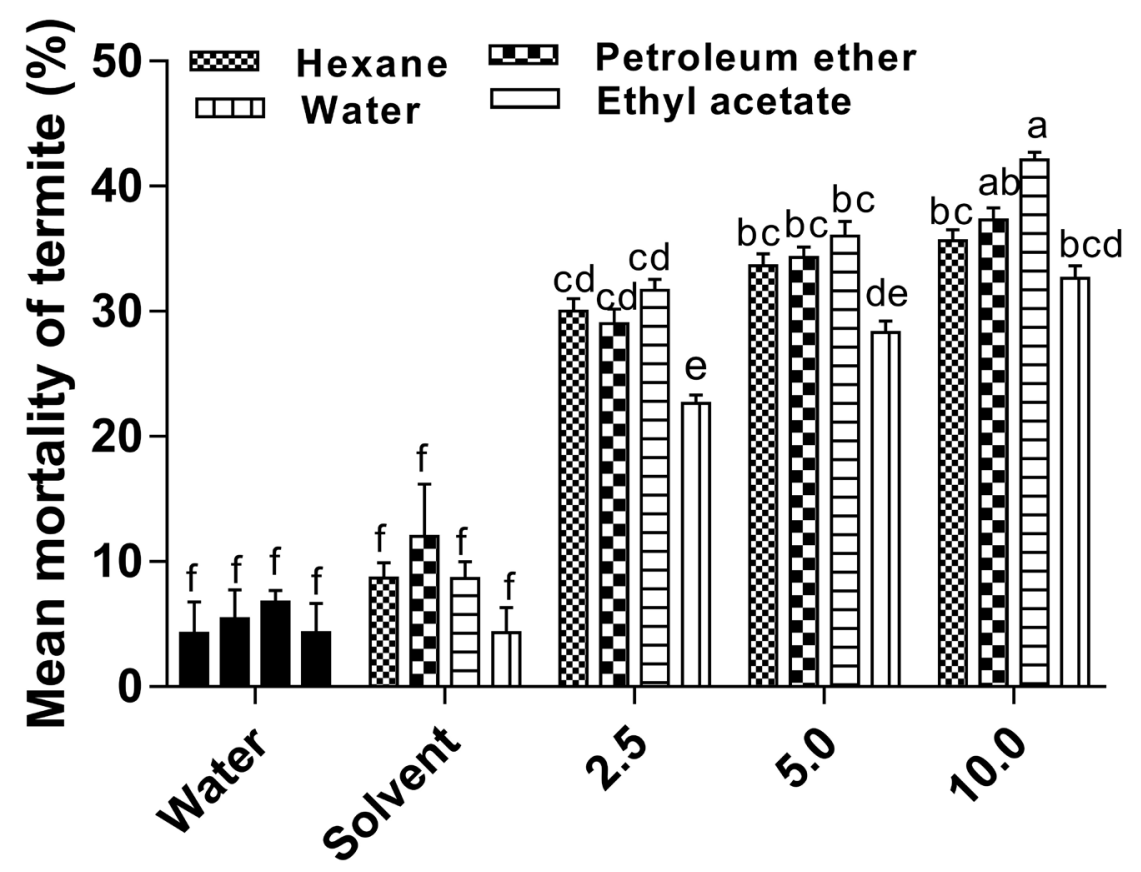

Concentrations $(\mathrm{mg} / \mathrm{ml})$

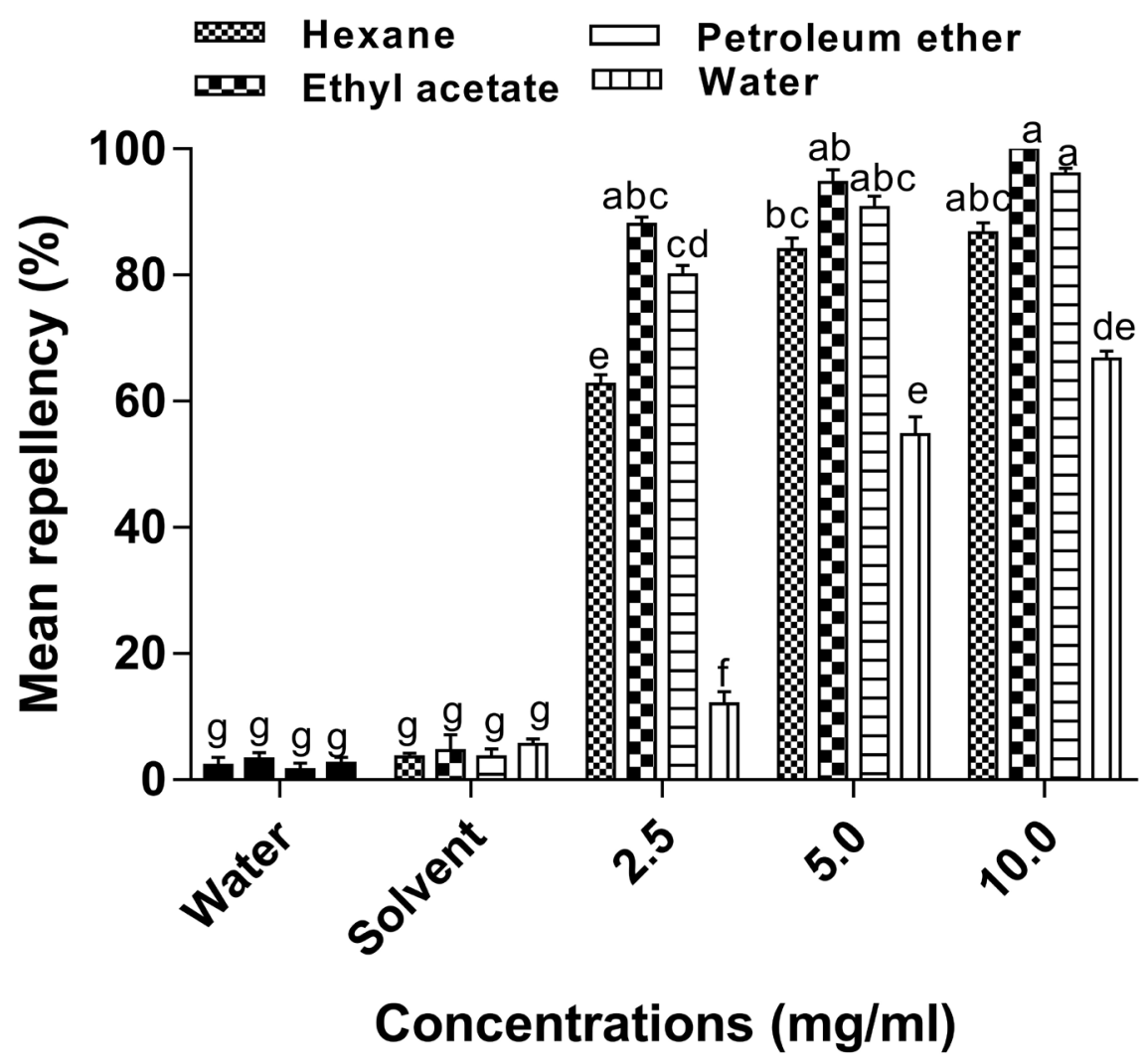

Figure 1. Mortality of termites exposed to different concentrations of $\mathrm{n}$-Hexane, petroleum ether, ethyl acetate, and water extracts of $P$. pinnata wood. Means sharing different letters are significantly different from one another. $F=6.60, p<0.05$.

Figure 2. Repellent effect of n-Hexane, petroleum ether, ethyl acetate, and water extracts of $P$. pinnata wood against termites. Means sharing different letters are significantly different from one another. $F=14.32, p<0.05$. 


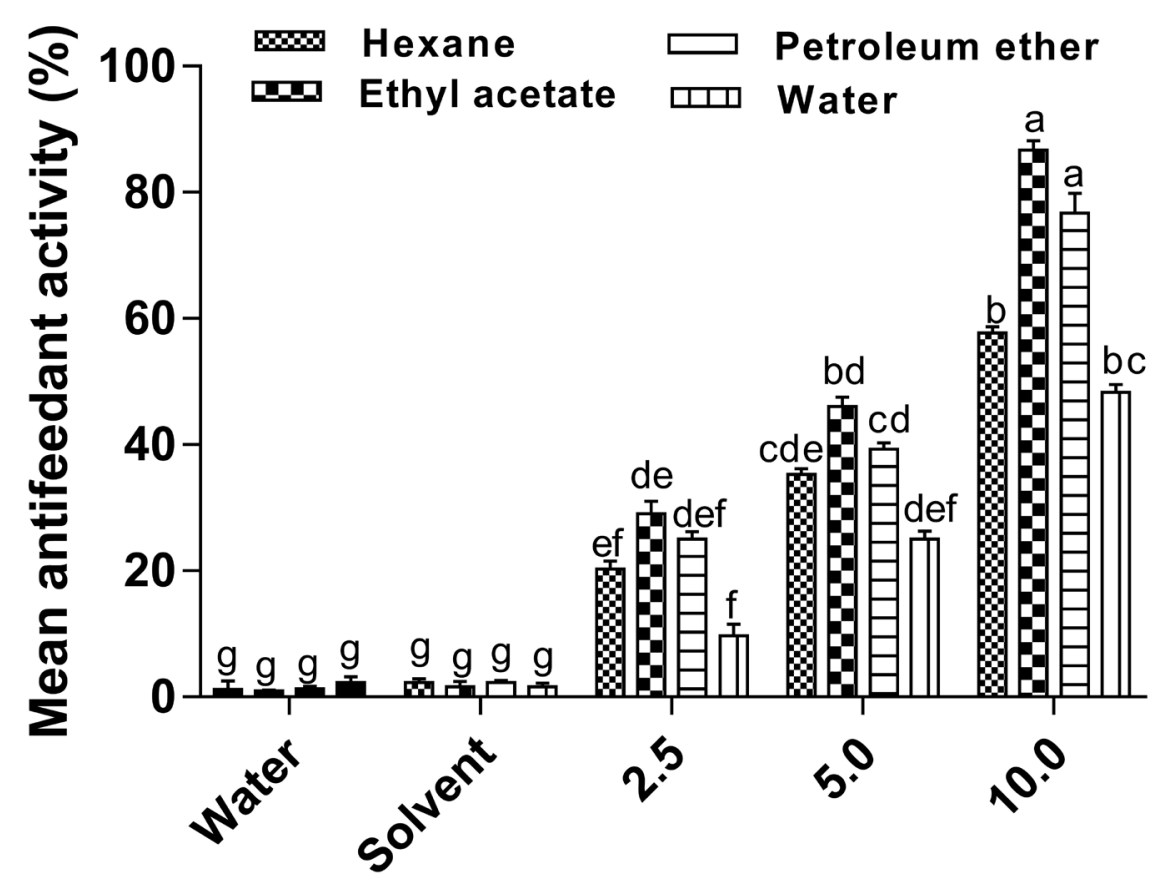

Concentrations $(\mathrm{mg} / \mathrm{ml})$

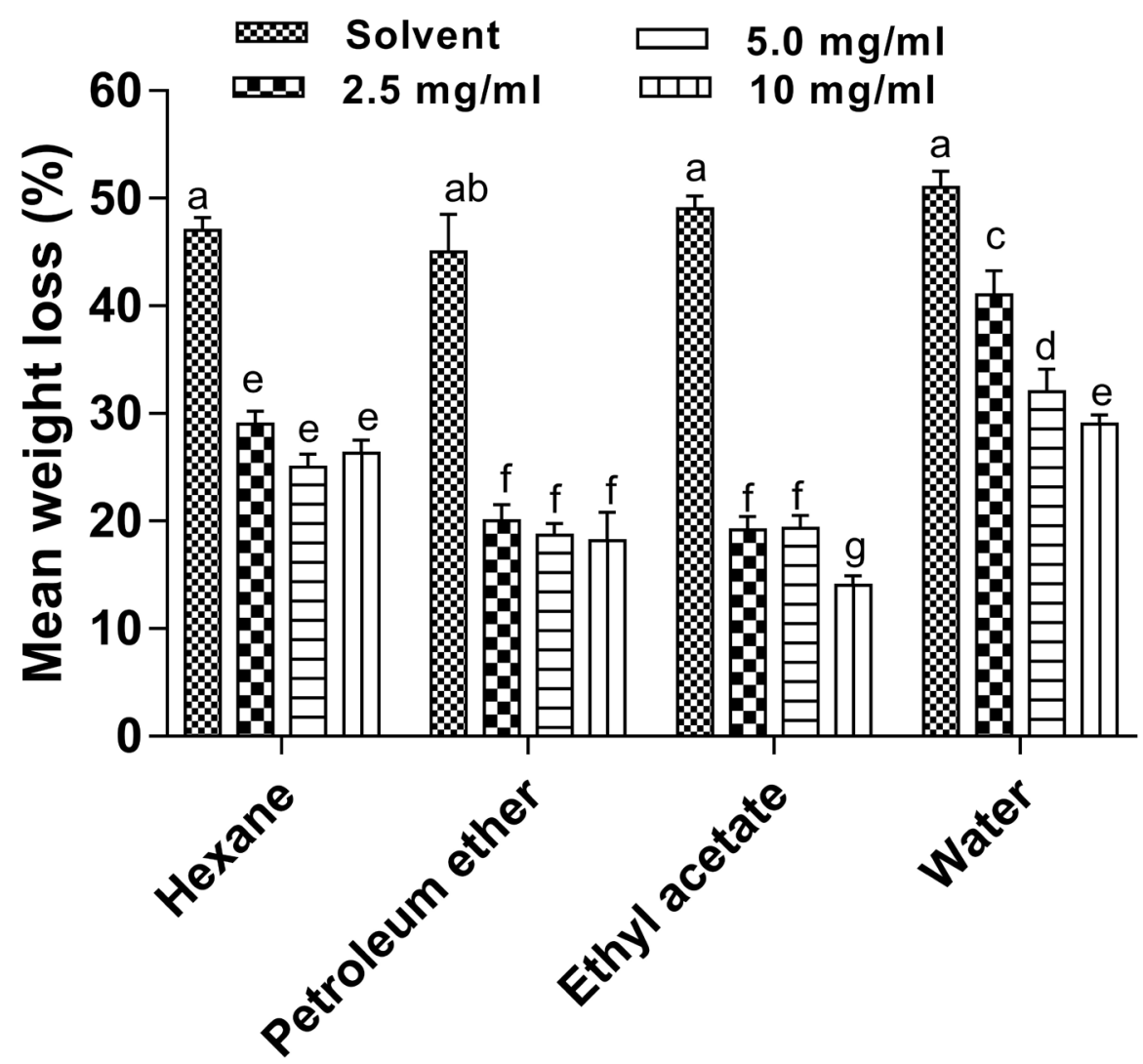

Solvents
Figure 3. Antifeedant activities of different concentrations of n-Hexane, petroleum ether, ethyl acetate, and water extracts of $P$. pinnata wood against termites. Means sharing different letters are significantly different from one another. $\mathrm{F}=3.03, \mathrm{p}<0.05$.

Figure 4. Mean weight loss of $P$. deltoides stakes dipped in different concentrations of n-Hexane, petroleum ether, ethyl acetate, and water extracts and exposed to termites in the field. Means sharing different letters are significantly different from one another. $F=44.37, p<0.05$. 


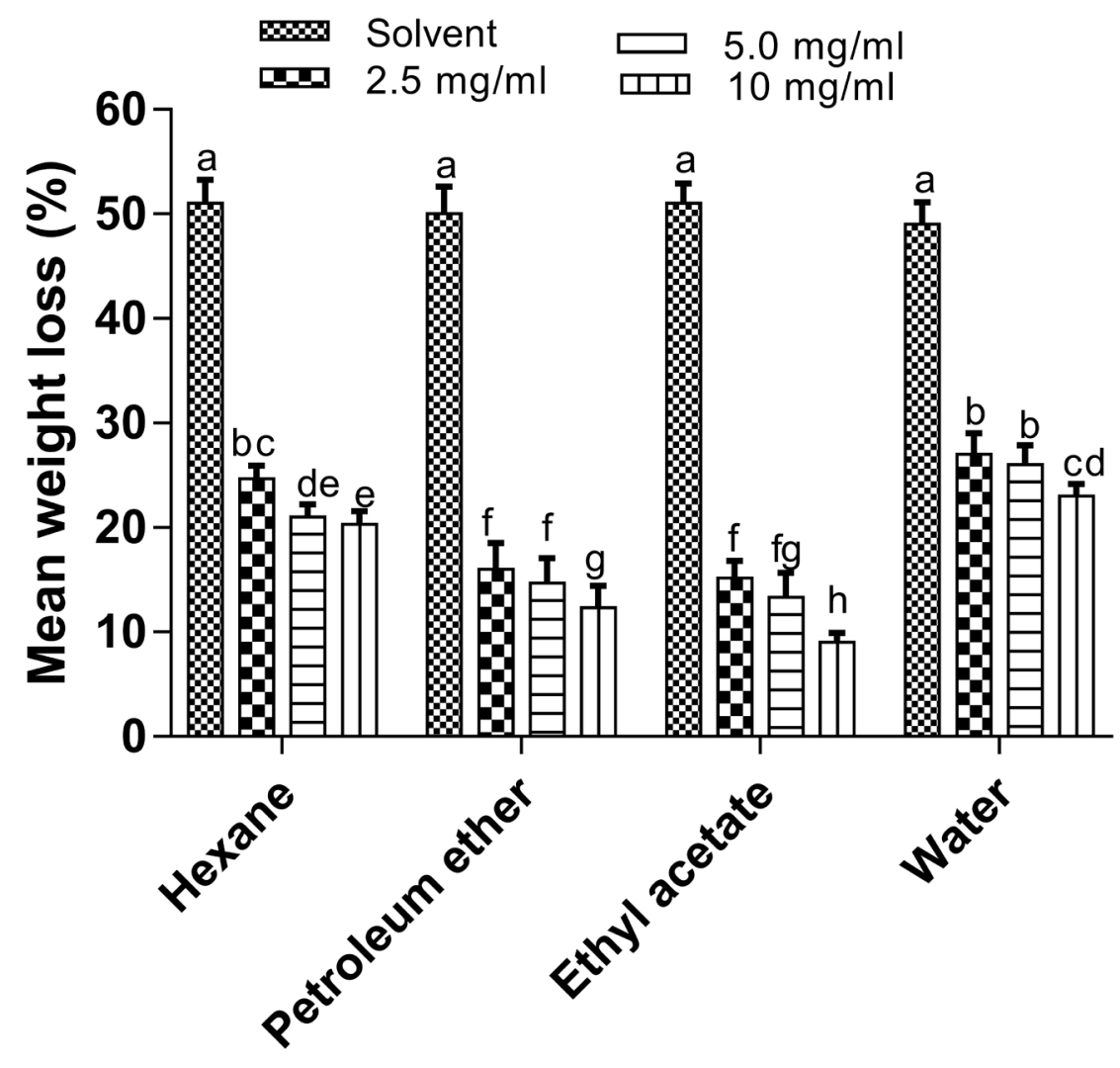

Figure 5. Mean weight loss of $P$. deltoides stakes pressure treated with different concentrations of $n$-Hexane, petroleum ether, ethyl acetate, and water extracts and exposed to termites in the field. Means sharing different letters are significantly different from one another. $F=49.39, p<0.05$.

\section{Solvents}

\section{DISCUSSION}

Natural resistance of dried $P$. pinnata wood was confirmed under field conditions using choice and no-choice tests. Wood extracts in organic solvents exhibited higher toxicity, repellent, and antifeedant activities than other solvents and water, especially at the highest concentration. Wooden stakes treated with ethyl acetate extracts had significantly lower weight loss as compared to other solvent extracts. Leaf and seed extracts of $P$. pinnata have been explored earlier as the insecticide, particularly Pongamia oil has been implicated in several bioassays with insects other than termites (Hiremath et al. 1997, Pavela 2009, Samuel et al. 2009, Reena et al. 2012, Al-Solami et al. 2014). Yet, the termiticidal potential of non-edible oil seedcakes, including Pongamia (karanja) and their crude active component (karanjin), has not been evaluated previously against Coptotermes heimi. In previous studies, Crude extracts of P. pinnata caused $83.3 \%$ mortality of Odontotermes obesus (Rambur) after 2 hours of exposure while all termites were dead after 4 hours in Petri plates (Sharma et al. 2011). Verma et al. (2011) observed that the petroleum ether extracts of $P$. pinnata and J. curcas seeds caused $100 \%$ mortality of Odontotermes obesus after 6 hours of exposure. Previous studies showed that stem wood and other parts of Pongamia contain a larger amount of flavonoids such as kaempferol, desmethoxykanugin, tetra-o-methyl fisetin, karanjin, and kanugin. These flavonoids usually involved in the protection of wood against harmful abiotic as well as biotic factors. Plant flavonoids affect insect cytochrome P-450 dependent steroid hydroxylases and act as 
antifeedant and digestibility reducers in insects (Rangaswami et al. 1942, Murti \& Seshadri 1945, Mitchell et al. 1993, Mierziak et al. 2014). Previous studies showed that $P$. pinnata extracts are quite effective against pests of stored grains and field crops and household insect pests (Kumar \& Singh 2002).

Pongamia pinnata oil also increased termites' resistance of treated wood compared J. curcas and S. glauca oils in the previous studies. Up to only $10 \%$ deterioration was observed in wood specimens treated with pure and copperized Pongamia oil (Venmalar 2017). Results showed significantly less weight loss of P. deltiodes than the control treatment; however, complete protection of treated wood was not found (Ahmed et al. 2014, Abbas et al. 2016).

In the field experiments, $P$. deltoides wooden stakes impregnated with extracts through dipping and vacuum pressure techniques resulted in low weight loss compared to control treatments. The reduction in weight loss due to ethyl acetate extract was $82 \%$. These results are in agreement with those described by AntwiBoasiako \& Damoah (2010), Syofuna et al. (2012), Kirker et al. (2013), Adeduntan (2015), Hassan et al. (2016) and Adedeji et al. (2017), but extracts were of different wood species.

Results of this study indicated that P. pinnata heartwood extract had a significant negative impact on termite activity. These wood extracts were repellent, termiticidal, and antifeedant to tested termite species. Tested wood extracts provided resistance of non-durable $P$. deltoides. These are foundational studies to establish the biological relevance of $P$. pinnata heartwood extract. Future studies will provide a targeted investigation of extract components to isolate bioactive properties from ethyl acetate extracts against termites.

\section{REFERENCES}

ABBAS M, AHMED S, HASSAN B \& NISAR MS. 2016. Termiticide activity of seed extract/oils from Schinus molle $L$ against subterranean termites under laboratory conditions. Intern J Biol Biotech 13: 633-636.

ADEDEJI GA, OGUNSANWO OY \& ELUFIOYE TO. 2017. Quantifications of phytochemicals and biocide actions of Lawsonia inermis Linn. Extracts against wood termites and fungi. Int Biodeterior Biodegrad 116: 155-162.

ADEDUNTAN SA. 2015. The termicidal effect of some plant material on some selected wood species. Int J Biol Chem Sci 9: 986-995.

AHMAD M. 1955. Termites of West Pakistan. Biologia 1: 202-264.

AHMED S, ARSHAD M \& HASSAN B. 2017. Comparative Efficacy of Synthetic Resins on Various Woods against Subterranean Termites. Pakistan J Zool 49: 1337-1341.

AHMED S, FATIMA R, NISAR MS \& HASSAN B. 2014. Evaluation of castor bean oil on Acacia nilotica as wood preservative against Odontotermes obesus (Ramb.) (Termitidae: Isoptera). Int Wood Prod J 5: 5-10.

AHMED S, HASSAN B, SALEEM MU, RIAZ MA \& NISAR MS. 2018. Efficacy of heartwood extractives of Albizia lebbeck (L.) benth. against subterranean termites. Int Wood Prod J 9(4): 194-199.

AHMED S, NAQVI SKA, SHERAZI AA, HASSAN B, RIAZ MA \& MAJEED Mz. 2016. Hygroscopic Properties following drying affect wood consumption by Odontotermes obesus. MaderasCienc Tecnol 18(4): 627-632.

AKHTAR MS. 1975. Taxonomy and zoogeography of termites of Bangladesh. Bulletin of the Department of Zoology, University of the Punjab, article 7, p. 1-99.

AL-SOLAMI HM, SALEH MS, AL-GHAMDI KM, ABUZINADAH OA \& MAHYOUB JA. 2014. Susceptibility of Aedes aegypti (L.) larvae to some non-conventional insecticides. Biosci Biotechnol Res Asia 1: 749-753.

ANTWI-BOASIAKO C \& DAMOAH A. 2010. Investigation of synergistic effects of extracts from Erythrophleum suaveolens, Azadirachta indica, and Chromolaena odorata on the durability of Antiaris toxicaria. Int Biodeterior Biodegrad 64: 97-103.

CHOPADE VV, TANKAR AN, PANDE VV, TEKADE AR, GOWEKAR NM, BHANDARI SR \& KHANDAKE SN. 2008. Pongamia pinnata: Phytochemical constituents, traditional uses and pharmacological properties: A review. Int I Green Pharm 2: $72-75$. 
FATIMA R, AHMED S, ARSHAD M \& SAHI ST. 2015. Effect of seasoning of different woods on resistance against Odontotermes obesus (Ramb.) under laboratory and field choice and no-choice test. BioResources 10: 6363-6377.

GONZÁLEZ-LAREDO RF, ROSALES-CASTRO M, ROCHA-GUZMÁN NE, GALLEGOS-INFANTE JA, MORENO-JIMÉNEZ MR \& KARCHESY JJ. 2015. Wood preservation using natural products. Madera Bosques 21: 63-76.

HASSAN B, AHMED S, KIRKER G, MANKOWSKI ME \& MISBAHUL-HAQ M. 2018b. Antioxidant effects of four heartwood extractives on midgut enzyme activity in Heterotermes indicola (Blattodea: Rhinotermitidae). Environ Entomol 47(3): 741-748.

HASSAN B, AHMED S, MEHMOOD N, MANKOWSKI ME \& MISBAH-ULHAQ M. 2019a. Toxicity potential of heartwood extractives from two mulberry species against Heterotermes indicola. Maderas-Cienc Tecnol 21(2): 153-162.

HASSAN B, MANKOWSKI M, KIRKER G, AHMED S \& BOYD B. 2016. Antitermitic activities of shisham (Dalbergia sissoo Roxb.) heartwood extractives against two termite species. IRG/WP 16-10856, 47 th IRG Ann. Meeting, 15-19, May, Lisbon, Portugal, 16 p.

HASSAN B, MANKOWSKI ME, KIRKER G \& AHMED S. 2017. Effects of heartwood extractives on symbiotic protozoan communities and mortality in two termite species. Int Biodeterior Biodegradation 123: 27-36.

HASSAN B, MANKOWSKI ME, KIRKER G, AHMED S \& BISHELL A. 2019b. Ex-situ performance of extracts from naturally durable heartwood species and their potential as wood preservatives. Eur J Wood Wood Prod 77(5): 869-878.

HASSAN B, MANKOWSKI ME, KIRKER GT, CLAUSEN CA \& AHMED S. 2018a. Effects of white mulberry (Morus alba) heartwood extract against Reticulitermes flavipes (Blattodea: Rhinotermitidae). J Econ Entomol 111(3): 1337-1345.

HIREMATH IG, AHN YJ \& KIM SI. 1997. Insecticidal activity of Indian plant extracts against Nilaparvata lugens (Homoptera: Delphacidae). Appl Entomol Zool 32: 159-166.

KADIR R, ALI NM, SOIT Z \& KHAMARUDDIN Z. 2014. Antitermitic potential of heartwood and bark extract and chemical compounds isolated from Madhuca utilis Ridl. H. J. Lam and Neobalanocarpus heimii King P. S. Ashton. Holzforschung 68: 713-720.

KAUR PJ, SATYA S, PANT KK \& NAIK SN. 2016. Eco-friendly preservation of bamboo species: Traditional to modern techniques. Bioresources 1: 10604-10624.

KIRKER G, BLODGETT A, ARANGO R, LEBOW P \& CLAUSEN C. 2013. The role of extractives in naturally durable wood species. Int Biodeterior Biodegrad 82: 53-58.
KUMAR M \& SINGH R. 2002. Potential of Pongamia glabra V. as an insecticide of plant origin. Biol Agric Hort 20: 29-50.

MIERZIAK J, KOSTYN K \& KULMA A. 2014. Flavonoids as important molecules of plant interactions with the environment. Molecules 19: 16240-16265.

MITCHELL MJ, KEOGH DP, CROOKS JR \& SMITH SL. 1993. Effects of plant flavonoids and other allelochemicals on insect cytochrome p-450 dependent steroid hydroxylase activity. Insect Biochem Mol Biol 23: 65-71.

MURTI PBR \& SESHADRI T. 1945. Chemical examination of the flowers of Pongamia glabra and a note on the glycosidic components of Butea frondosa flowers. Proc Indian Acad Sci Section A 20: 279-291.

PAVELA R. 2009. Effectiveness of some botanical insecticides against Spodoptera littoralis Boisd. (Lepidoptera: Noctudiae), Myzus persicae Sulzer (Hemiptera: Aphididae) and Tetranychus urticae Koch (Acari: Tetranychidae). Plant Prot Sci 45: 161-167.

RANGASWAMI S, RAO JV \& SESHADRI T. 1942. Kanugin, a crystalline component of the roots of Pongamia glabra. Proc Indian Acad Sci Section A 16: 319.

REENA, SINGH R \& SINHA BK. 2012. Evaluation of Pongamia pinnata seed extracts as an insecticide against American bollworm Helicoverpa armigera (Hubner). Int J Agric Sci 4: 257.

SAGWAN S, RAO D \& SHARMA RA. 2012. In vivo and in vitro proportional antimicrobial activity in karanja (Pongamia pinnata): An imperative leguminous tree. Int J Res Rev Pharm Appl Sci 2: 981-995.

SAMUEL AJSJ, RADHAMANI S, GOPINATH R, KALUSALINGAM A, VIMALA AGKA \& HUSAIN HA. 2009. In vitro screening of anti-lice activity of Pongamia pinnata leaves. Korean J Parasitol 47: 377-380.

SANGWAN S, RAO DV \& SHARMA RA. 2010. A review on Pongamia pinnata (L.) Pierre: A great versatile leguminous plant. Nat Sci 8: 130-139.

SHARMA S, VERMA M, PRASAD R \& YADAV D. 2011. Efficacy of non-edible oil seedcakes against termite (Odontotermes obesus). J Sci Ind Res 70: 1037-1041.

SYOFUNA A, BANANA AYE \& NAKABONGE G. 2012. Efficiency of natural wood extractives as wood preservatives against termite attack. Maderas-Cienc Tecnol 14: 155-163.

VENMALAR D. 2017. Screening of Oils of Pongamia pinnata Linn., Jatropha curcas Linn. And Simarouba glauca D.C. for Developing Eco-Friendly Wood Preservatives. In: Pandey K, Ramakantha V, Chauhan S \& Kumar A (Eds). Wood is Good. Singapore, Springer 1: 261-267. 
VERMA M, PRADHAN S, SHARMA S, NAIK SN \& PRASAD R. 2011. Efficacy of karanjin and phorbol ester fraction against termites (Odontotermes obesus). Int Biodeteri Biodegrad 65: 877-882.

\section{How to cite}

AHMED S, TABASSUM MH \& HASSAN B. 2022. Evaluation of Antitermite Properties of Wood Extracts from Pongamia pinnata (L.) Pierre (Leguminosae) against Subterranean Termites. An Acad Bras Cienc 94: e20190591. DOI 10.1590/0001-3765202220190591.

Manuscript received on May 22, 2019;

accepted for publication on November 19, 2019

\section{SOHAIL AHMED ${ }^{1}$}

https://orcid.org/0000-0002-8455-6342

\section{MUZAMMAL H. TABASSUM}

https://orcid.org/0000-0002-0748-068X

\section{BABAR HASSAN ${ }^{1,2}$}

https://orcid.org/0000-0003-0824-1258

${ }^{1}$ Termite Research Laboratory, Department of Entomology, University of Agriculture, Faisalabad, University Rd,

Police Lines, Faisalabad, Punjab, 38000, Pakistan

${ }^{2}$ National Centre for Timber Durability \& Design Life, University of the Sunshine Coast, Ecosciences Precinct, 41 Boggo Road, Dutton Park, Queensland, 4102, Australia

Corresponding author: Babar Hassan

E-mail:sialuaf@gmail.com,bhassan@usc.edu.au

\section{Author contributions}

Sohail A conceived the idea and supervised the experiments. Muzammal HT performed the experiments in the lab and field. Babar $\mathrm{H}$ contributed with the data analysis and wrote the manuscript. All authors have read and approved the final manuscript.

\section{(cc) BY}

